Wioletta Hajduk-GaWron

(D) https://orcid.org/0000-0001-6978-127X

Hankuk Univeristy of Foreign Studies

Seul

\title{
Sfera linguakultury jako niezbędny element integracji
}

The lingua-cultural sphere as an essential element of integration

\begin{abstract}
The paper addresses the aspect of lingua-culture and its role in teaching Polish among students with migration experiences at a Polish school. Polish as the language of school education serves as a tool used in the process of learning about the world, but it is also a guarantee of efficient social integration. Moving smoothly within the lingua-cultural sphere (deciphering cultural codes hidden in the language) in the case of users of the language who come from a different linguistic and cultural background enables free communication as well as a sense of connection with the host environment. The author supports this proposition with theoretical interpretations (Edward Sapir's and Claire Kramsch's views) as well as with practical experience of a foreign language teacher, using the example of selected literary texts (the work of Grzegorz Kasdepke).
\end{abstract}

Key words: lingua-culture, inclusion, integration, Polish language glottodidactics, students with migration experience

Język polski jako: ojczysty (pierwszy), obcy, drugi, odziedziczony, język szkolnej edukacji - to terminy nieobce glottodydaktykom polonistycznym. W ostatnich latach stają się one coraz bardziej wyraziste i poparte licznymi badaniami naukowymi, gdyż określenia te uwarunkowane sa sposobem i miejscem opanowywania języka. Języka polskiego uczą się w polskich szkołach nie tylko rodzimi użytkownicy języka urodzeni w Polsce, ale - w wyniku napływu do Polski osób powracających z emigracji - ludności z innych krajów, np. Europy Wschodniej, również osoby z doświadczeniem migracji. Będą to zatem uczniowie cudzoziemscy szkół podstawowych, którzy w wyniku zmiany miejsca pracy rodziców i zamieszkania całej rodziny zmieniaja też miejsce dotychczasowej edukacji, będą to osoby już dorosłe, absolwenci szkół ponadpodstawowych, którzy edukację wyższą zaczynają w Polsce. 
Niejednokrotnie osoby te nie znają dobrze języka polskiego, uczą się go dopiero podczas rocznego kursu przygotowawczego, a po jego ukończeniu moga podjąc studia na wybranym kierunku, często też zostają w Polsce na stałe. Polszczyznę opanowują również dzieci Polaków zamieszkałych poza granicami Polski, w tym przypadku jest to nierzadko nauka języka polskiego jako drugiego, odziedziczonego lub jako obcego. Tajniki języka polskiego zgłębiają też studenci programów studenckich Erasmus Plus, lecz wydaje się, że ich celem najczęściej nie jest uzyskanie wysokiej biegłości językowej, a przede wszystkim przygoda z językiem obcym w obcym kraju, w nowej kulturze. To właśnie miejsce pobytu uczących się i cel procesu dydaktycznego wpływają na zróżnicowaną nomenklaturę pojęć z zakresu glottodydaktyki, nie tylko polonistycznej.

W każdej z opisywanych sytuacji dydaktycznych nauczany język jest narzędziem poznania. W przypadku uczniów z doświadczeniem migracyjnym (bez względu na poziom edukacji) umiejętne nim władanie jest zarówno gwarancja poszerzania wiedzy z danego przedmiotu i zdobycia wykształcenia, jak również skutecznym sposobem na integrację ze środowiskiem przyjmującym. W obliczu powszechnych migracji, czasowych lub stałych pobytów w obcym kraju, uczęszczania do szkół lub uniwersytetów uczniów i studentów, dla których język polski nie jest językiem ojczystym, pojawia się pytanie, jak wykorzystać tę sytuację nie tylko w celu edukacyjnym, ale też społeczno-integracyjnym? (Grossman 2019). Jak sprawić, by dzieci rozpoczynające naukę w polskiej placówce edukacyjnej szybko poczuły się swobodnie nie tylko w szkole, ale też poza nią, aby umiały włączyć się w życie społeczności, w której są przybyszami?

Jaka jest rola w tym procesie języka edukacji szkolnej? Na potrzeby niniejszego tekstu omówię to pojęcie, nie wyodrębniając innych kluczowych dla glottodydaktyki polonistycznej zagadnień, takich jak język odziedziczony, drugi i obcy, ponieważ dla moich rozważań istotne jest przede wszystkim scharakteryzowanie polszczyzny jako języka edukacji szkolnej. Uczą się go i używają uczniowie z doświadczeniem migracji w Polsce, a jego opanowanie bezpośrednio wiąże się z procesem poznania i zrozumienia świata. Język edukacji szkolnej pełni jednocześnie trzy role (Schleppegrell 2012). Po pierwsze, jest przedmiotem nauczania, a celem, ku któremu zmierza proces dydaktyczny, jest rozwój kompetencji komunikacyjnej (umożliwiającej m.in. funkcjonowanie w szkole i zwykłe codzienne porozumiewanie się), dzięki poznawaniu podsystemów języka i rozwijaniu sprawności językowych. Po drugie, jest to medium pozwalające na zdobywanie wiedzy przedmiotowej, 
między innymi za pomocą słownictwa specjalistycznego. To, jaka leksyka powinna być uwzględniona na poszczególnych poziomach zaawansowania językowego, wynika ze współpracy nauczycieli poszczególnych przedmiotów z glottodydaktykami polonistycznymi. Po trzecie wreszcie, język polski jest także narzędziem samorealizacji: dzięki niemu odbywa się rozwój indywidualny i społeczny, co oznacza, że brak jego znajomości opóźnia możliwość pełnego rozwoju albo wręcz go uniemożliwia (za Pamuła-Behrens 2018, 178). Rozumieć i być rozumianym to klucz do sukcesu komunikacyjnego i czynnego uczestnictwa w kulturze kraju osiedlenia ${ }^{1}$.

W niniejszym artykule szczególnie zajmie mnie język edukacji szkolnej uczniów z doświadczeniem migracji i jego wzbogacanie poprzez poznawanie linguakultury kraju osiedlenia i umiejętne wprowadzanie w jej sferę. Odniesieniem teoretycznym będzie antropologiczne i kulturowe podejście Edwarda Sapira do językoznawstwa oraz transkulturowa koncepcja Claire Kramsch. W drugiej części artykułu podejmę próbę połączenia wykładni teoretycznej z praktyką lektorską na przykładzie tekstów literackich, niektóre z nich ze względu na swoją tematykę wydają się stosowne dla odbiorcy młodszego (8-10 lat), lecz dla kreatywnego nauczyciela i otwartego ucznia ograniczenia te wydają się bez znaczenia.

Zwięźle przypomnę podstawy przywołanych koncepcji. Tradycja antropocentrycznego i kulturocentrycznego opisu lingwistyki reprezentowana przez Sapira ${ }^{2}$ jest niezwykle bliska glottodydaktyce. Ucząc (się) języka obcego, nie możemy pominąć kontekstu kulturowego i językowego obrazu świata spo-

\footnotetext{
${ }^{1}$ Pomijam w tym miejscu strategie akulturacyjne wybierane przez przybyszów - zarówno uczniów, jak i rodziców, bo one również mają silny wpływ na proces przyswajania języka kraju osiedlenia i proces integracji (por. Hajduk-Gawron 2019). Innym przykładem może być fragment reportażu Ewy Winnickiej, w którym zamieszczono relacje polskich emigrantów z ich życia w Wielkiej Brytanii i sposoby dobierania strategii akulturacyjnych: „Trzecia tajemnica kodu to język angielski. Oni mają lekką obsesję na punkcie swojego języka. Czują, że przestali być jego właścicielami. (...) Dlatego ja poświęcam czas, by zgłębić tę specyficzna frazeologię, którą posłużą się tylko Anglicy. Wiem, czym różni się sofa od settee albo mebla zwanego couch. Odróżniam toilet od loo. Mówię: We can do it in a nick of time, mówię: It's a real dog's breakfast, it's a hospital pass i widzę w oczach człowieka, że kolejny kod zostaje złamany. Jestem prawie z ich klasowego stada, troszkę mniej obcokrajowcem” (Winnicka 2014, 44-45).

${ }^{2} \mathrm{Na}$ temat historii myśli naukowej dotyczącej języka jako czynnika, który określa, a nawet determinuje obraz świata - por. Żurek 2010, na temat hipotezy Sapira-Whorfa (determinizmu oraz relatywizmu językowego, hipotezy, która ma swoje mocne i słabe strony, jak również zwolenników i przeciwników) - por. Klimczuk 2013, na temat językowego obrazu świata por. np. Bartmiński 2001; Anusiewicz, Dąbrowska, Fleischer 2000.
} 
łeczności (rodzimych użytkowników języka), która danego języka używa do wyrażania emocji, poznawania i opisu świata:

Dla Sapira język był zjawiskiem fascynującym, ponieważ był w jego oczach kluczem do zrozumienia całego ludzkiego świata. Język był kluczem do kultury, kluczem do myśli. Świat ludzki tym się różni od świata nauk przyrodniczych, że jest to świat znaczeń. Studiować formy języka w oderwaniu od myśli, jakie się za tymi formami kryją, to tak jak studiować zewnętrzne formy kultury - tatuaże, ceremonie, rytuały - w oderwaniu od ich znaczeń i funkcji. Język był dla Sapira aspektem kultury (ze wstępu Anny Wierzbickiej, Sapir 1978, 19-20).

Za tą samą myśla podąża postawa orędowniczki transkulturowości Claire Kramsch (1993), która przedkłada ponad wszystko znajomość kontekstu i kultury w nauczaniu języka obcego i czytaniu literatury przez odbiorcę zewnętrznego kulturowo i językowo. Traskulturowość proponowana przez Kramsch otwiera „trzecią przestrzeń” (Kramsch 1993, 9), która oznacza różnicę w odbiorze tekstu spowodowaną odmiennością indywidulanych doświadczeń czytelników. Potwierdza tym samym tezę Sapira, iż nie należy skupiać się jedynie na badaniu tekstów, a również na tajemnicy ludzkiego umysłu: „Zrozumienie na przykład prostego wiersza zakłada nie tylko rozumienie pojedynczych słów w ich zwykłym znaczeniu, lecz pełną znajomość całego życia społeczności odzwierciedlonego w słowach lub sugerowanego przez towarzyszące im skojarzenia" (Sapir 1987, 88). Mamy tym samym dwie ścieżki odczytań tekstów literackich i ich roli w procesie glottodydaktycznym: interkulturowa prowadzi do wielości interpretacji, kulturowa z kolei pozwoli wydobywać ukryte w języku przekazy kulturowe prowadzące do poznania i zrozumienia zjawisk przynależnych do danej społeczności.

Skojarzenia, o których mowa, ułatwiające zrozumienie komunikatu, mieszczą się w sferze linguakultury. Pojęcie wykreowane przez Michaela Agara, a wprowadzone na polski grunt przez Grażynę Zarzycką (2004), definiuje się jako: „językowy obraz wartości, symboli, sensów charakterystycznych dla danego obszaru kulturowego" (Zarzycka 2004, 436). Ponadto Zarzycka wyróżnia linguakulturę narodową, środowiskową lub peryferyjną, która wyraża się poprzez idiolekt jednostki. Mowa każdego człowieka określa bowiem jego stosunek do wartości kultury. Według tej teorii język i kultura występuja jako całość, albowiem język przenosi i przechowuje wartości utrwalone w kulturze. Linguakultura jest porównywana do 
przestrzeni, którą rodzimi użytkownicy języka zamieszkują i kształtują, nie zawsze mając tego świadomość. To, co dla natywnych użytkowników języka w danej kulturze jest swojskie, często bywa też traktowane bezrefleksyjnie. Inaczej jest w przypadku reprezentantów innych kultur uczących się języka, dla których brak znajomości tych powiązań może prowadzić do poważnych trudności komunikacyjnych (chodzi tu np. o wtrącanie w codziennych rozmowach cytatów z filmów, piosenek czy książek powszechnie znanych, przysłów, wyrażeń idiomatycznych oraz ich użycie w tekstach pisanych) ${ }^{3}$. Zamieszkanie na dobre w przestrzeni linguakultury danej społeczności przez użytkownika zewnętrznego językowo i kulturowo to proces długotrwały i obarczony dużym wysiłkiem zarówno ze strony nauczycieli, jak i uczących się ${ }^{4}$. W sukurs przychodzi literatura, której tkanką jest język pełen naturalnych użyć i kontekstów, bo - cytując Ryszarda Koziołka z książki pt. Dobrže się myśli literatura $(2016,7)$ - „literatura to konieczność mówiącego człowieka, który w trosce o biologiczny i społeczny byt musi ulepszać swoją mowę, czyli czytać oraz tworzyć metafory i opowieści” i dalej „Mamy tylko literaturę, by doskonalić myślenie, czyli świadome nazywanie i porozumiewanie się" $(2017,11)$.

Chciałabym zatem uczynić czytanie (tekstów literackich) medium w kształceniu inkluzyjnym, bo jak zauważa przywołany już literaturoznawca:

Mediacyjna funkcja literatury jest dziś rzadko podnoszona, a wydaje mi się jej najważniejszą funkcją społeczną. Osłabienie literatury jako dostarczycielki języka, tradycji, form symbolicznych, za pomocą których

3 Próbą przybliżenia odbiorcom (zewnętrznym językowo i kulturowo, uczącym się języka polskiego jako obcego na poziomach od B1) cytatów z polskiej poezji i dramatu funkcjonujących w polszczyźnie jako skrzydlate słowa jest publikacja Na wyrywki. 100 cytatów z polskiej poezji $i$ dramatu, które powinien znać takize cudzoziemiec (zob. Cudak, Hajduk-Gawron, Madeja 2018).

${ }^{4}$ Warto w tym miejscu wspomnieć o transjęzykowości, czyli etapie, na którym trudno jeszcze mówić o pełnym uczestnictwie uczących się języka w sferze linguakultury. Transjęzykowość to stosunkowo najnowsza metoda czy też sposób służący porozumieniu w określonej sytuacji życiowej, w nauczaniu szkolnym, a także w szkolnictwie wyższym. To podejście społeczno-edukacyjne dopuszcza stosowanie różnorodnej wiedzy językowej ułatwiającej porozumienie i komunikację, w odróżnieniu od podejścia filologicznego, które podkreśla pełne opanowanie leksyki i reguł języka. Podejście to zakłada możliwość mieszania języków (code-switching) na różnych poziomach - leksykalnym, gramatycznym i składniowym, jak również przechodzenie z jednego języka na drugi. Transjęzykowość oznacza zatem tworzenie niezbędnych znaczeń, początkowo bez całościowej znajomości nabywanego języka, a w kolejnych etapach - używanie go z coraz większą wiedzą i kompetencją (Grossman 2019). 
jednostki rozpoznają się jako członkowie wspólnoty, nie spowodowało, że w to opuszczone przez literaturę miejsce wszedł na przykład film. (...) Dziś znów uważam, że nic nie zastapiło literatury i nic nie jest w stanie jej zastąpić. Ludzie mogą nie czytać, tylko że są wtedy pozbawieni pewnej dyspozycji intelektualnej, której nie sposób nabyć inaczej (Koziołek 2015, 16-17).

Proponuję tu lekturę adresowaną do młodszego czytelnika, ucznia szkoły podstawowej, która wprowadza zarówno w świat języka, jak i w świat kultury, bo zgodnie z założeniami linguakultury, to język przechowuje kulturę społeczności, która go używa. Pomocna okaże się twórczość Grzegorza Kasdepkego, jego zagadki detektywistyczne z detektywem Pozytywką w roli głównej oraz dowcipne przykłady użycia idiomów w komunikacji codziennej przedstawione w zbiorze Co to znaczy....: 101 zabawnych historyjek, ktore pozwola. zrozumiec znaczenie niektorych powiedzen. Lamigłówki te opierają się na koncepcie nakłaniania czytelników do poszukiwania odpowiedzi na podstawie logicznego myślenia, czasem opartego na grze słów, bądź na znajomości sensów powiedzeń, które kryją w sobie np. stereotypy. Za przykład niech posłuży zagadka zatytułowana Kawa po turecku, oto jej fragment ${ }^{5}$ :

- Wolę kofii - mruknął Turek.

- Wspaniale! - krzyknął detektyw Pozytywka. - Zaparzę panu kawę po turecku! (...) po czym wsypał do filiżanki półtorej łyżeczki kawy i zalał ja wrzątkiem.

(...)

- Proszę... - powiedział, stawiając na stoliku filiżankę. - Pańska kawa. Zaparzona po turecku, z fusami.

- Ciekuje. - Turek ukłonił się lekko. - Wsapniale kofii, ciekuje. Jak w domu, w Turcja.

(...) - Musie już iść! Ale wrócic, obiecuje! (...)

- To nie był prawdziwy Turek. - Detektyw Pozytywka się uśmiechnął.

- Tyle wiem na pewno. Myślę, że był to ucharakteryzowany Martwiak.

Zagadka: Tak, Turek nie był tak naprawdę Turkiem, tylko przebierańcem. Jak sądzisz, co sprawiło, że detektyw Pozytywka domyślił się prawdy? (Kasdepke 2007, 100-105) ${ }^{6}$.

\footnotetext{
${ }^{5}$ Stylizacja językowa i błędy w pisowni zachowane zgodnie z oryginałem.

${ }^{6}$ Rozwiązanie zagadki: „(...) Zdaniem wielu osób kawa po turecku to zwykła, nierozpuszczalna kawa, którą należy zalać wrzątkiem i pić, nie zważając na osadzające się na dnie fusy. Tymczasem prawdziwy Turek na widok takiej kawy ryknąłby tylko śmiechem. Kawa po tu-
} 
Kluczem do rozwikłania tej zagadki jest znajomość tego, co kryje się w idiomie kawa po turecku. Powiedzenie to odzwierciedla stereotypowe wyobrażenie Polaków, obecne w języku i kształtujące językowy obraz świata, w jaki sposób pije się kawę w Turcji (a jest on zgoła inny niż wskazuje praktyka polska). Lektura tego opowiadania może być początkiem zabawy z innymi powiedzeniami, które utrwalają stereotypowe wyobrażenie Polaków o różnych nacjach, np.: wyjść po angielsku, francuski piesek, czeski film, czeski błąd, cygańskie dziecko, ruski rok, ryba po grecku, pierogi ruskie, barszcz ukraiński, siedzieć po turecku itd. Zaproponowanie tropu wyszukiwania związku języka z kulturą i stereotypem nosi również znamiona wychowania międzykulturowego tak potrzebnego w polskich klasach coraz częściej niejednorodnych językowo i kulturowo ${ }^{7}$.

$\mathrm{Na}$ linguakulturę składa się również kultura dnia codziennego, choćby takie elementy jak przyzwyczajenia żywieniowe i słownictwo z tym związane, ale również istotne dla danej społeczności lub narodu daty, bowiem celebrowanie niektórych świąt wyznacza rytm życia społeczności np. szkolnej:

(...) - Panie Pozytywka! (...) - Pomocy, ktoś ukradł kwiaty! Detektyw Pozytywka osłupiał. Po co ktoś miałby kraść stojące na klatce schodowej kwiaty?! Ale kwiatów rzeczywiście nie było. (...) - A ja wiem, czyja to sprawka... - usłyszeli naraz chełpliwy głos Martwiaka - Siedzi już u mnie w piwnicy! (...) - Czy pan zwariował?! - wykrztusił detektyw Pozytywka. - Pani Ryczaj w życiu by niczego nie ukradła!

- A to niby co?! - zapytał Martwiak, wskazując ogromny bukiet różnorodnych kwiatów. - I to ma być nauczycielka... po prostu wstyd! (...)

(...) - Pani Ryczaj jest lubiana nawet przez łobuzów - westchnął ciężko [Pozytywka - W.H.-G.]. - I możliwe, że dostała od nich jakieś kwiaty.

- Wie pan, który dzisiaj mamy? - zapytał detektyw Pozytywka. czternasty października... (...) Pani Ryczaj jest niewinna.

Zaga d k a: Jak sądzisz, dlaczego detektyw Pozytywka był pewny, że pani Ryczaj jest niewinna, mimo iż niosła aż kilka bukietów? I jaki związek ma z tym wszystkim data czternasty października? (Kasdepke 2007, 89-93).

recku, jaką piją niektórzy Polacy, nie ma nic wspólnego z kawa, jaką piją Turcy. A zatem, gdy gość detektywa Pozytywki zapewniał, że taką właśnie kawę pił u siebie w domu, odkrył tym samym swoją niewiedzę" (Kasdepke 2007, 243). Kawa po turecku to metoda parzenia kawy, która polega na zagotowaniu w małym miedzianym naczyniu drobno mielonej kawy z dodatkiem cukru, następnie płyn zlewa się do małej filiżanki.

${ }^{7} \mathrm{Na}$ temat pomysłów zajęć obalających stereotypy narodowościowe por. Janus-Sitarz 2004, 475-481. 
Innym przykładem rozszyfrowywania utartych powiedzeń w języku polskim jest frazeologia ukazana w zabawnych historyjkach, co ułatwia zapamiętywanie kolokacji oraz prawidłowego kontekstu ich użycia:

1.

Mamo!... - Bartuś przybiegł do domu wzburzony.

- Dlaczego mi nie powiedziałaś?!...

- Ale czego?! - Mama była wyraźnie zdumiona.

- Że urodziłem się z dwiema lewymi rękoma. Mama parsknęła śmiechem. Bartusia rozsierdziło to jeszcze bardziej.

- Próbowałem już kilka razy zreperować rower Aśki i nic mi nie wychodziło. Zastanawiałem się nawet dlaczego?... No i dzisiaj Aśka powiedziała, że pewnie mam dwie lewe ręce - dlatego. To może być prawda, bo niby dlaczego z tym rowerem tak mi nie idzie?

Mama skręcała się ze śmiechu.

- Jeżeli ktoś coś robi - wyjaśniła wreszcie - ale mu to wyraźnie nie wychodzi, to wtedy mówi się o takiej osobie, że ma dwie lewe ręce. Niektórzy mają je na przykład do sprzątania, a inni do reperowania rowerów. Wystarczy jednak potrenować, by mieć do wszystkiego dwie prawe ręce! (Kasdepke 2001, 36-37).

2.

- Tato? ... - Bartuś stanął między kanapą a telewizorem. - Pójdziesz ze mną na podwórko?...

- Po co?... - jękną tata. - Oglądam film...

- Pogramy w piłkę - kusił Bartuś. - Możemy popuszczać latawca... Tata zrobił nieszczęśliwą minę.

- Głowa mnie boli - wystękał - poza tym mam duszności!...

- Bo za mało się ruszasz! - powiedział zdenerwowany Bartuś. Chodź, porzucamy sobie słowa na wiatr!. ...Tata wybałuszył na Bartusia oczy. - Co ty gadasz? - spytal zaskoczony.

- No, chyba lubisz to robić? - odpowiedział niespeszony Bartuś. Babcia mówiła, że często rzucasz sło...

- Babcia żartowała! - przerwał mu tata. - Rzucać słowa na wiatr to znaczy obiecywać coś, a potem nie dotrzymywać słowa!... A ja babci zreperuję tę pralkę, zobaczysz! Idziemy! - zerwał się z kanapy.

- Dokąd?! - Tym razem to Bartusia zatkało.

- Na basen! - Tata ruszył do przedpokoju.

- Obiecałem przecież, że pójdziemy na basen!

- Ale to było przed wakacjami! - wybełkotał Bartuś.

- Nieważne kiedy! - wykrzyknął tata. - Grunt to nie rzucać słów na wiatr! (Kasdepke 2001, 56-57). 
Przytoczone wyimki literackie sięgają do zasobów sfery linguakultury polskiej głównego nurtu (Zarzycka 2004, 441), z której swobodnie korzystają rodzimi użytkownicy języka. Poddani regularnej edukacji, uczestnicząc w życiu kulturalnym, choćby w ograniczonym stopniu, nabywają tę kompetencję w sposób naturalny. Osoby uczące się języka polskiego jako obcego w warunkach szkolnych często mają inną biografię edukacyjną, dlatego właśnie na zajęciach językowych, których celem jest wyrównanie poziomu językowego tak, aby uczeń mógł skutecznie poszerzać wiedzę z innych przedmiotów ${ }^{8}$, teksty literackie mogą być sposobem na wprowadzenie w sferę linguakultury. Znajomość kontekstu kulturowego, historycznego czy politycznego bywa konieczna przy wzorcowej interpretacji np. tekstu poetyckiego ${ }^{9}$, może być zupełnie pominięta w myśl transkulturowości i odczytania sensu utworu zgodnie z doświadczeniem i stanem wiedzy odbiorcy, może też być barierą komunikacyjna lub prowadzić do nieporozumień. Repertuar linguakulturowy osób młodych często ulega ciąłym zmianom, gdyż to właśnie one na skutek procesu edukacyjnego i przebywania w różnych grupach rówieśniczych wzbogacają wiedzę i słownictwo z wielorakich dziedzin, kształtując w ten sposób swój styl komunikowania się.

Przywołane w pierwszej części artykułu teorie prezentują nierozerwalny związek między nauką czy też przyswajaniem języka a znajomością kultury lub środowiska, które wytworzyło dany system języka. Znajomość ta i płyn-

8 Zgodnie z Rozporządzeniem Ministra Edukacji Narodowej z dnia 1 kwietnia 2010 r. w sprawie przyjmowania osób niebędących obywatelami polskimi do publicznych przedszkoli, szkól, zakładów kształcenia nauczycieli i placówek oraz organizacji dodatkowej nauki języka polskiego, dodatkowych zajęć wyrównawczych oraz nauki języka i kultury kraju pochodzenia, Dziennik Ustaw Nr 57, poz. 361: „Cudzoziemcy podlegający obowiązkowi szkolnemu lub obowiązkowi nauki, którzy nie znają języka polskiego albo znają go na poziomie niewystarczającym do korzystania z nauki, mają prawo do dodatkowej, bezpłatnej nauki języka polskiego w formie dodatkowych zajęć lekcyjnych z języka polskiego. Dodatkową naukę języka polskiego organizuje gmina lub powiat właściwe ze względu na miejsce zamieszkania cudzoziemca. Korzystanie przez cudzoziemców z dodatkowych zajęć z języka polskiego nie jest ograniczone czasowo. Cudzoziemcy moga korzystać także z dodatkowych zajęć wyrównawczych z danego przedmiotu przez 12 miesięcy. Łączny wymiar dodatkowych zajęć z języka polskiego i zajęć wyrównawczych nie może przekroczyć 5 godzin tygodniowo na każdego ucznia”.

${ }^{9}$ Przykłady objaśnień tekstów poetyckich wspomagających zanurzenie się w świat języka docelowego (polskiego) i linguakulturę (polska) por. Na wyrywki. 100 gytatón z polskiej poezji i dramatu, które powinien znać takize cudzoziemiec (Cudak, Hajduk-Gawron, Madeja 2018), np. hasła: A niechaj narodowe wżdy postronni znaja/ I $\dot{z}$ Polacy nie gesi, iz swój jezylk maja!; Litwo! Ojczyzno moja!; Mimozami jesień sie zaçyna; Ocalałem/ prowadzony na rzeź, Pan tu nie stat. 
ne poruszanie się w kodach kulturowych, oczywiście nie od razu, lecz w miarę rozwoju języka, wpływa na poczucie wspólnoty i integracje społeczną użytkowników zewnętrznych językowo i kulturowo, zaś lektura odpowiednio dobranych tekstów literackich (stosownie do wieku i zainteresowań) sprzyja edukacji inkluzyjnej, a tym samym integracji społecznej, która polega na zachowaniu własnych i przyswajaniu nowych, właściwych innej kulturze wartości ${ }^{10}$.

Wykorzystywania tekstów literackich w procesie kształcenia kompetencji językowych i kulturowych nie można zaniechać i należy szukać coraz to nowszych sposób i kontekstów na wprowadzanie ich w proces edukacyjny. Wydaje się, że współczesna kultura obrazkowa oraz szybki dostęp do informacji i wiedzy za pomoca piśmiennictwa internetowego może zdominować i wyprzeć tradycyjne czytelnictwo. Pomimo tych obaw należy jednak dostrzec i wykorzystać fakt, że aktywność czytelnicza (i piśmiennicza) przybiera obecnie wielorakie formy dzięki piśmiennictwu internetowemu, bardzo rozwiniętej komunikacji mailowej11 i czatowej na różnych komunikatorach, to właśnie tu, w przestrzeni wirtualnej, kształtują się równiez kompetencje czytelnicze i pisarskie młodych użytkowników języka (i nie tylko młodych, bo przecież liczną grupę tych, którzy uprawiają ten rodzaj czytelnictwa czy piśmiennictwa stanowią osoby, które już dawno zakończyły proces edukacji zinstytucjonalizowanej).

Trud poznawania linguakultury zostaje wynagrodzony swoboda komunikacyjną i wzbogacaniem stylistyki wypowiedzi poprzez trafne użycie porównań lub odpowiednie wplatanie do wypowiedzi cytatów z różnych tekstów kultury. Odrębne rozważania należą się kwestii, czy obcokrajowiec mówiący po polsku może w pełni mówić (i pisać, chodzi przede wszystkim o sprawności produktywne), tak jak rodzimy użytkownik języka - w modelu idealnym, do którego chcielibyśmy dążyć - z pewnością tak. Jednak praktyka lektorska pokazuje, że język polski (po wyuczeniu prawideł wymowy, opanowaniu leksyki i reguł gramatycznych) w wykonaniu przedstawicieli różnych

${ }^{10} \mathrm{O}$ istotnej roli literatury w kształceniu międzykulturowym uczniów z doświadczeniem migracyjnym por. Krasuska-Betiuk, Kotarba 2017.

${ }^{11}$ To w sytuacji podawania danych kontaktowych (jedna z pierwszych lekcji dla początkujących) studenci dowiadują się, że powszechnie używany znak@w języku przynależnym do słownictwa komputerowego nie zawsze jest odczytywany za pomoca internacjonalizmu, jak to ma miejsce w przypadku nomenklatury informatycznej, ale często nosi nazwę z zakresu fauny: np. 'małpa' po polsku, 'pies' po rosyjsku, 'ślimak' po koreańsku, 'rolmops' (zawijany marynowany śledź) po czesku. 
kultur, przywykłych do odmiennych systemów gramatycznych nie jest tym samym językiem z perspektywy składni czy stylistyki.

\section{Literatura}

Anusiewicz J., Dą̧browska A., Fleischer M., 2000, Jesykony obraz świata $i$ kultura, w: Dąbrowska A., Anusiewicz J., red., Ježylkony obraz swiata i kultura, Wrocław.

Bartmiński J., 2001, O jesylkonym obrazie śniata Polakón końca XX wieku, w: Dubisz S., Gajda S., red., Polszcryzna XX wieku. Ewolucja i perspektyny rozwoju, Warszawa.

Cudak R., Hajduk-Gawron W., Madeja A., red., 2018, Na myrywki. 100 cytatów z polskiej poezji $i$ dramatu, które powinien znać takìe cudzoziemiec, Katowice.

Grossman E., 2019, O zjawisku „transjesy/kowości” (translanguaging) na proykkładzie brytyjskiej literatury dzieciecej o tematyce migracyjnej, w: Frukacz K., red., Literatura polska w swiecie. Recepcja i adaptacja - mecenaty i migracje. Prace ofiarowane profesorowi Romualdowi Cudakowi, Katowice.

Hajduk-Gawron W., 2019, Strategie akulturacyjne a glottodydaktyka, w: Frukacz K., red., Literatura polska w swiecie. Recepcja i adaptacja - mecenaty i migracje. Prace ofiarowane profesorowi Romualdowi Cudakowi, Katowice.

Janus-Sitarz A., 2004, Stereotypy narodowościone a nauczanie jesylka polskiego jako obcego, w: Dąbrowska A., red., Wroctawska dyskusja o jesylku polskim jako obcym. Materialy z. miedzynarodowej konferencii Stowaryyszenia „Bristol”, Wrocław.

Kasdepke G., 2007, Wielka ksiega detektywa Posytywki, Warszawa.

Kasdepke G., 2001, Co to znacsy....: 101 zabawnych historyjek, które pozpoola zrozumié́ znaczenie niektórych powiedzeń, Łódź.

Klimczuk A., 2013, Hipoteza Sapira-Whorfa - Przeglad argumentón zuolenników i przecinnikón, „Kultura - Społeczeństwo - Edukacja”, nr 1 (3), Poznań.

Koziołek R., 2016, Dobrze sie myśli literatura, Katowice.

Kramsch C., 1993, Context and Culture in Language Teaching, Oxford.

Krasuska-Betiuk M., Kotarba M., 2017, Edukacja jesykowa drieci imigrantów. Perspektywa glottodydaktyki interkulturowej, w: Markowska-Manista U., Pasamonik B., red. nauk., Kryyys migracyjny. Perspektywa pedagogiczno-psychologiczna, t. 2, Warszawa.

Pamuła-Behrens M., 2018, Jesylk edukacji szkolnej w integracyjnym modelu wsparcia ucznia z dośniadczeniem migracii w rodzinie, „Postscriptum Polonistyczne”, nr 2.

Sapir E., 1978, Kultura, jesylk, osobowość, przeł. Stanosz B., Zimand R., wstęp Wierzbicka A., Warszawa.

Winnicka E., 2014, Angole, Wołowiec.

Zarzycka G., 2004, Linguakultura - caym jest, jak ja badać i „otwierać”, w: Dąbrowska A., red., Wroctawska dyskusja o jesyku polskim jako obcym. Materiaty z miedrynarodowej konferencji Stowaryyszenia „Bristol”, Wrocław.

Żuk G., 2010, Jesykony obraz śniata w polskiej lingwistyce przetomu wieków, w: Karwatowska M., Siwiec A., red. Przeobrażenia w jesyku $i$ komunikacii medialnej na przetomie XX $i$ XXI wieku, Chełm. 


\section{Netografia}

Schleppegrell M.J., 2012, Academic Language in Teaching and Learning Introduction to the Special Issue, „The Elementary School Journal”, vol. 112, no. 3, Chicago, http://www.jstor.org/stab le/10.1086/663297 [dostęp: 04.07.2019]. 